\title{
Journal of Public Administration Studies
}

e-ISSN 2541-6979

\author{
URL: http://www.jpas.ub.ac.id/index.php/jpas
}

\section{Public Policy Instruments Selected in Policy Implementation Prostitution Prevention and Revocation in Surabaya City}

\author{
Nurul Umi Ati ${ }^{\mathrm{a}} *$ \\ ${ }^{a}$ Unisma Malang, East Java Indonesia
}

\section{ARTICLE INFORMATION}

\section{Article history:}

Data submission : 10 June 2020

$1^{\text {st }}$ revision: 10 August 2020

Accepted: 16 November 2021

Available online: 10 December 2021

Keywords: Public Policy Instruments, Implementation, Prostitution

\begin{abstract}
This study aims to analyze public policy instruments chosen in the implementation of prostitution prevention and repetition policies in the city of Surabaya. This type of research is a qualitative descriptive study with a focus of research analyzing Voluntary Model Instruments, Mixed Model Instruments and Mandatory Instruments (Regulations). Novelty (novelty) of this research is to see the reality of the problem of prostitution by looking at the public policy instruments chosen in the implementation of prostitution prevention and repetition policies. The results showed that from the voluntary model instrument, commercial sex workers (CSWs) had been given skills training as well as spiritual spray/recitation on a regular basis to then be repatriated to their home areas with compensation. But not all sex workers want compensation. Residents of Dolly and Jarak held a bulletin board after hundreds of residents burned tires in the middle of the road as a refusal.
\end{abstract}

2021 FIA UB. All rights reserved.

\section{Introduction}

Nationally the normative basis in the prevention and control of prostitution is the 1945 Constitution Article 31 concerning Educating, that: Every citizen has the right to receive teaching; and in Article 34 concerning: The poor and neglected children are cared for by the State. This can be seen from the background of women falling into prostitution activities. In Indonesia the authority in the prevention and control of the problem of protection is implemented into a public policy by the regional government based on Law No. 32 of 2004 concerning Regional Government, namely decisions that bind to the people at the strategic or outline level made by public authorities.

Based on BKKBN data statistics on premarital sexual behavior of adolescents from year to year are increasing. The era of 1970, research on premarital sex behavior showed a figure of $7-9 \%$. In the 1980 s, this number increased to $12-5 \%$. In 1990 it increased to $20 \%$. In this era of 2000 , it was found that $26.35 \%$ of teenagers had premarital sex. BKKBN data shows an increase in the number of Indonesian adolescents who have pre-marital sex, in 2005-2006 in major cities in Indonesia, the rate of premarital sex in adolescents was $47.54 \%$. However, the results of the $2008 \mathrm{BKKBN}$ last survey increased to 63\%. In addition, data from the National Family Planning Coordinating Board show that $51 \%$ of teenagers in Jabodetabek have pre-married and in Surabaya $54 \%$ of female adolescents are not virgins. Looking at the data from ILO - IPEC above, in 2007 Surabaya ranked the highest in Indonesia with the number of commercial sex workers, moreover they were below the age of 18 and girls in Surabaya were not virgins (54\%) higher than Jabotabek teenagers, then it is appropriate for the East Java provincial government to make rules and be able to implement them well.

As for the authority of the normative base area is Regional Regulation No. 7 of 1999 issued by the Government of the Municipality of Level II Surabaya and established on May 11, 1999 is a regulation concerning the prohibition on using buildings or places for immoral acts as well as attachments to conduct

* Corresponding author. Tel.: +62-816-1560-0557; e-mail: atiek.sulistiyono@gmail.com 
immoral acts in Surabaya. This regulation was realized by the closing of the Dolly Gang Localization in Jarak Pasar Kembang area on June 18, 2014. The above regional regulations have been established since May 11, 1999 but have not been implemented for a long time because of the obstacle Dolly has transformed into a living support for residents in surrounding area.

After Dolly was closed at that time, the government as a policy maker and implementor was faced with the challenge of being able to overcome the existing prostitution problem, considering that the government's function in dealing with prostitution issues was empirically carried out by the Surabaya City Social Service on the basis of laws and regional regulations it requires technical rules that reach more problems in the field in a concrete way, especially as the proliferation of prostitution is hidden in cafes, food stalls, restaurants, massage parlors, karaoke places, hotels, beauty and fitness salons, and even now in place of boarding houses. This became a heavy homework for the Surabaya Regional Government, but it was undeniable that a major achievement in Surabaya had succeeded in closing Dolly's localization as the largest prostitution place in Southeast Asia. This proves as one of the manifestations of the successful implementation of the Surabaya government policy in the prevention and control of prostitution. In connection with the successful closure of the Dolly localization above, in order to be able to achieve the realization of the implementation of prevention and overcoming prostitution policies maximally and sustainably, Indonesia can emulate the State of Sweden as stated by Social Minister Khofifah Indar Parawansa, "for the national level the government is striving for Indonesia to implement policies like Sweden in overcoming prostitution". From the description above, it proves that the Surabaya City Government and the Swedish State have succeeded in using Government policies as the basis for prevention and prevention of prostitution. Of course, it depends on the ability of the actors implementing policy in collaborating, strategies and various supporting factors that influence it.

\section{Theory}

Policy implementation according to Hill and Hupe, (2002). simply means "what happens between policy expectations and (perceived) policy results" (what happens between policy expectations and (considered) policy outcomes and has two characters "... a concern to explain what happens and a concern to affect what happens "(attention to explain what happened and attention to influence what happened).

The government has several instruments that can influence society and economic stability that are capable of producing changes to the lives of citizens. As where O'Toole (1998) interpret policy instruments as "the results of choice made for influencing behavior, and sometimes institutional arrangements, from target in the future policy". The concept of the instrument itself can be clarified by making the distinction of an instrument as an object and an instrument as an activity. Instruments as objects, often in the legal literature people say laws and administrative orders as an instrument, while instruments as activities, are a set of activities that focus on the influence and management of social processes (O'Toole, 1998).

Howlett and Ramesh (1995) are more detailed and detailed to make the characteristics of policy instruments into three, namely: voluntary instruments (mixed instruments), mixed instruments (mixed instruments) and compulsory instruments (mandatory instruments). Each instrument has a series and diversity of tools that can be used as instruments for implementing policies, in accordance with policy issues to be solved.

Prostitution or Commercial Sex Workers are derived from the Latin pro-stature, which means allowing yourself to commit adultery, committing delinquency, molestation, and struggle. Prostitutes are prostitutes or bitches, also known as WTS or prostitutes (Kartono, 2005). Prostitution is an uncivilized act because the destruction of sexual relations in the form of surrender to many men, for sexual gratification, is rewarded for services or money from their services. Moral can also be said to be an act that fails to adjust to the norms of morality.

\section{Research Method}

This type of research is qualitative research, namely research used to test the condition of natural objects where researchers are key instruments (Sugiyono, 2005). Based on the type of data and analysis, this research is descriptive qualitative, which aims to describe and analyze public policy instruments selected in the implementation of policies on prevention and repetition of prostitution in the city of Surabaya. The focus of this research is the public policy instruments chosen in the implementation of prostitution prevention and repetition policies in the city of Surabaya which include:

a. Voluntary model (family, community, voluntary organization, market),

b. Mix (information, warnings, subsidies)

c. Mandatory instrument (regulation)

The research location is in accordance with the research title, namely in the city of Surabaya where Dolly was located. The data collection technique used in this study is using techniques:

1. Interview

Interviews were conducted in the form of more complete, in-depth and accurate data collection to help researchers to analyze research problems more sharply on public policy instruments selected in the implementation of policies on prevention and repetition of prostitution in the city of Surabaya.

2. Observation 
Observations made were related to public policy instruments chosen in the implementation of prostitution prevention and repetition policies in the city of Surabaya

3. Documentation

Analyzing books or literature relating to research especially, the Surabaya City Social Service Archives, documentation, and journals relating to documents relevant to this research the author gets through the government, namely from the Social Service, in the form of data and information regarding sources of policy and various forms of prostitution prevention and control policies in the city of Surabaya. Whereas the data obtained from the community in the former Dolly localization site are data relating to various supporting documentation relating to the implementation of the Surabaya prostitution prevention and prevention policy.

The analysis technique used in this study is qualitative data analysis techniques. According to Miles, Huberman and Saldana (2014) in the analysis of qualitative data there are three lines of activities that occur simultaneously. Activities in data analysis are: data condensation, data display, and conclusion drawing/verifications.

\section{Results}

The instruments chosen in the implementation of Prostitution prevention and control policies in the City of Surabaya include the following.

4.1. Voluntary Model Instruments, including: Family and Community, Voluntary Organizations, Markets

Commercial sex workers (CSWs) have been given skills training as well as spiritual spraying / recitation regularly by the Social Service Office of the City of Surabaya in collaboration with Putat Jaya Urban Village with relevant agencies and universities and community social institutions and individual volunteers. Follow-up from the spiritual shower program and skills training for the commercial sex workers recorded 630 PSK data were successfully repatriated by the Surabaya City Government to return to their home areas and handed over to their families at the time of the closing of Dolly Jarak.

When closing the localization of Dolly Jarak PSK, which recorded 1564 people living in the lokalisasi, not all CSWs would be compensated to be returned to their families of origin, arguing that the prostitutes who were given compensation must fill their statements not to work as prostitutes again in the city Surabaya. In order for the economically affected community to rise again and stay alive after Dolly Jarak was closed, the Surabaya City Government together with the Putat Jaya Village Officials continuously and simultaneously held various skills training for Dolly Jarak residents according to the wishes of the people concerned, besides that many residents used to work as pimps, parking attendants, grocery traders, laundry, stall sellers, coffee shops, clothes sellers and street vendors, some people were employed in the Surabaya City Government Agency. The rest are successful in becoming entrepreneurs of Typical Dolly chips and crackers Symbols of Localization Change

\subsection{Mixed Instruments, including: Information and Warnings, Subsidies}

The closure of localization began with socialization involving all levels of the Surabaya City Government, the entire community in Dolly, local RT / RW, community leaders, religious leaders, and officials. Furthermore, a warning board was installed which also explained the threat to those who were determined to carry out the practice of prostitution installed by the Satpol PP, but the installation of a bulletin board at the end of Jalan Jarak or near Dukuh Kupang was challenged.

Residents of Dolly and Jarak carried out the burning of bulletin boards after hundreds of residents burned tires in the middle of the road as a refusal. Residents also attacked the police with stone throws. Thanks to the collaboration of the Surabaya City Government and the East Java Provincial Government through the Bureau of Community Welfare, a number of prostitutes (WTS) have been taken up. In addition to being given a $\mathrm{Rp} 3$ million allowance to go home, they were also provided with skills in the hope of having a work and not returning to work as WTS. However, the problem in the field is that many pimps are also RWs who enter the names of other people either from CSWs or not in the CSW data collection which will be submitted for compensation funds requests to the City Government in the hope that the compensation funds will be disbursed. outside or ordinary woman.

Fortunately, there was a re-checking of the data from the Kelurahan authorities so that the fake CSW data collection did not all pass, although there were still some who still escaped so that the pimps could benefit

\subsection{Mandatory instruments, including: Regulation}

The Surabaya City Government to prevent and control prostitution in Dolly Jarak provides facilities to expimps, future hopeful women (former CSWs) and affected communities, including: (1) The government buys ex-brothels in Dolly Jarak which are used for production centers, playgrounds, creative homes, mini futsal and so on. (2) Establish several UKM / KSM and (3) Carry out the Dolly Saiki Fest 2017 activity.

\section{Discussion and conclusion}

Based on the results of the data and discussion of the research findings described in the previous chapters, it can be concluded that the Implementation of Prostitution 
Prevention and Control Policies in Surabaya is not enough if analyzed through a policy implementation model but also needs to pay attention to Policy Instruments, including voluntary model instruments, mixed instruments and mandatory instruments (Howlett \& Ramesh, 1995).

Based on the public policy instruments chosen in the implementation of the policy of prevention and repetition of prostitution in the city of Surabaya, it is known that from the voluntary model instrument, commercial sex workers (CSWs) have been given skills training as well as spiritual spray/recitation regularly to later be repatriated by the City Government Surabaya to return to their home area and be handed over to their families at the time of the closing of Dolly Jarak, with compensation.

However, not all CSWs will be compensated for returning to their families, with the reason that the prostitutes who are given compensation must fill in their statements not to work as prostitutes again in the city of Surabaya. Based on mixed instruments, the closure of localization begins with socialization involving all ranks of the Surabaya City Government, the entire community in Dolly, local RT/RW, community leaders, religious leaders, and officials. Furthermore, a warning board was installed which also explained the threat to those who were determined to carry out the practice of prostitution installed by the Satpol PP, but the installation of a bulletin board at the end of Jalan Jarak or near Dukuh Kupang was challenged.

Residents of Dolly and Jarak held a bulletin board after hundreds of residents burned tires in the middle of the road as a refusal. Residents also attacked the police with stone throws. Other problems regarding compensation, many pimps who are also RWs who enter the names of other people either from CSWs or not in the CSW data collection will be submitted to be requested for compensation funds to the City Government in the hope that if the compensation funds are disbursed, they will be divided between pimps and Outside sex workers or ordinary women.

Based on mandatory instruments, the Surabaya City Government to prevent and control prostitution in Dolly Jarak provides facilities to ex-pimps, future hopeful women (former CSWs) and affected communities, including: The government buys ex-brothels in Dolly Jarak which are used for central activities. production centers, playgrounds, creative homes, mini futsal and so on; established several UKM /KSM and carried out the Dolly Saiki Fest 2017 Surabaya activity

\section{References}

Hill, M. \& Hupe, P. (2002). Implementing Public Policy: Governance in Theory and in Practice. Sage Publication.

Howlett, M. \& Ramesh, M. (1995). Studying Public Policy. Policy Studies Review, 12(1) 3-24.
Kartono, K. (2001). Psikologi Abnormal dan Abnormalitas Seksual. CV Mandar Maju.

Miles, M. B., Huberman, A. M., \& Saldana, J. (2014). Qualitative Data Analysis: A Method Sourcebook. Sage Publications.

Otoole, J. (1998). Leading Change: The Argument for Value-Based Leadership. Sage Publications.

Sugiyono. (2005). Memahami Penelitian Kualitatif. CV. Alfabeta. 